\title{
DAMPAK PSIKOLOGIS SISWA KORBAN BULLYING DI SMA NEGERI 1 BARUMUN
}

\author{
Erlina Harahap ${ }^{1}$, Nor Mita Ika Saputri ${ }^{2}$ \\ ${ }^{1}$ Lecturer of Guidance and Counseling, Universitas Muhammadiyah Tapanuli Selatan, South \\ Sumatera, Indonesia. \\ (erlina.harahap@um-tapsel.ac.id) \\ ${ }^{2}$ Lecturer of Guidance and Counseling, Universitas Muhammadiyah Tapanuli Selatan, South \\ Sumatera, Indonesia. \\ (normita.ika@um-tapsel.ac.id)
}

\begin{abstract}
The purpose of this study was to determine the psychological impact of victims of bullying on students of SMA Negeri 1 Barumun. Respondents in this study were two people who were taken purposively by criteria: a) women / men victims of bullying, b) class X da XI. Informants in this study were parents, teachers and one friend of each research respondent. This research method is qualitative with a phenomenological approach. Data collection techniques are carried out by observation, interviews, and documentation. Phenomenology data analysis stages are: 1) data organization, 2) coding and analysis, 3) testing of guesses, 4) important things as analysis strategies. The results of the study are: 1) the forms of bullying experienced by the subject in school are the three forms of bullying namely physical, verbal, and psychological bullying; 2) factors that cause students to be bullied, which tend to be due to students who are physically small and weak, students who lack confidence, are difficult to adjust to the environment, and are considered unattractive in adolescents such as students with brown skin, curly hair, and others; 3) bullying in schools has an impact that can hinder the development of students at school, victims of bullying are afraid and then withdraw from their classmates, become passive and feel less focused on participating in classroom teaching and learning activities.
\end{abstract}

Keywords: psychological impact, bullying

\begin{abstract}
Abstrak: Tujuan dari penelitian ini adalah untuk mengetahui dampak psikologis korban bullying pada siswa SMA Negeri 1 Barumun. Responden dalam penelitian ini adalah dua orang yang diambil secara purposive dengan kriteria : a) perempuan/laki-laki korban bullying, b) kelas X da XI. Informan dalam penelitian ini adalah orangtua, guru dan satu orang teman dari setiap responden penelitian. Metode penelitian ini adalah kualitatif dengan pendekatan fenomenologis. Teknik pengumpulan data dilakukan dengan observasi, wawancara, dan dokumentasi. Tahapan analisis data fenomenologi adalah : 1) organisasi data, 2) koding dan analisis, 3) pengujian terhadap dugaan, 4) hal-hal penting sebagai strategi analisis. Hasil penelitian adalah: 1) bentuk bullying yang dialami subjek di sekolah adalah ketiga bentuk bullying yaitu bullying fisik, verbal, dan psikologis; 2) faktor yang menyebabkan siswa dibully yaitu cenderung dikarenakan adanya siswa yang mempunyai fisik kecil dan lemah, siswa yang kurang percaya diri, susah menyesuaikan dengan lingkungan, dan dianggap tidak menarik di lingkungan usia remaja seperti siswa yang mempunyai kulit sawo matang, rambut ikal, dan lain sebagainya; 3) bullying di sekolah mempunyai dampak yang dapat menghambat perkembangan siswa di sekolah, korban bullying merasa takut lalu menarik diri dari teman-teman di kelas nya, menjadi pasif dan merasa kurang fokus mengikuti kegiatan belajar mengajar di kelas.
\end{abstract}

Kata kunci : dampak psikologis, bullying

\section{PENDAHULUAN}

Salah satu perilaku siswa yang banyak diperbincangkan adalah perilaku bullying sebagai bentuk penindasan terhadap korban yang lemah dengan melakukan hal-hal yang tidak disukai secara berulang. Bullying berasal dari kata bully yang artinya penggertak, orang yang mengganggu orang lain yang lebih lemah. Beberapa istilah dalam Bahasa Indonesia yang sering dipakai untuk menggambarkan fenomena bullying di antaranya adalah penindasan, 
'penggencetan', 'perpeloncoan', 'pemalakan', pengucilan, dan intimidasi.

Riauskina dkk. (2005) melakukan penelitian pada beberapa SMA di Jakarta dan Bogor, menemukan fakta bahwa bullying sudah menjadi tradisi siswa-siswi di SMA tersebut. Penelitian ini mencatat bahwa 'penggencetan' oleh kakak kelas pada adik kelas dapat dikategorikan menjadi dua jenis yaitu memarahi dan mengganggu. Adik kelas dimarahi ketika kakak kelas tidak suka, dan adik kelas diganggu ketika kakak kelas sedang ingin 'iseng'. Kondisi tersebut dapat membuat lingkungan sekolah menjadi tempat lahirnya premanpreman.

Di Indonesia, hal tersebut diatur dalam Undang-Undang Perlindungan Anak (UUPA) Nomor 23 Tahun 2002 pasal 54 menyatakan, "Anak di dalam dan di lingkungan sekolah wajib dilindungi dari tindakan kekerasan yang dilakukan oleh guru, pengelola sekolah atau teman-temannya di dalam sekolah yang bersangkutan, atau lembaga pendidikan lainnya". Bullying merupakan perilaku yang tidak bisa diterima secara sosial. Secara fisik, pelaku bullying tidak hanya didominasi oleh anak yang berbadan besar dan kuat, anak bertubuh kecil maupun sedang yang memiliki dominasi yang besar secara psikologis di kalangan teman-temannya juga dapat menjadi pelaku bullying. Alasan yang paling jelas mengapa seseorang menjadi pelaku bullying adalah bahwa pelaku bullying merasakan kepuasan apabila ia "berkuasa" di kalangan teman sebayanya. Selain itu, tawa teman-teman sekelompoknya saat ia mempermainkan korban memberikan penguatan terhadap perilaku bullying (Sejiwa, 2008).

Ardianti (2009) menemukan bahwa selain perasaan berkuasa, ada beberapa hal yang menyebabkan seseorang menjadi pelaku bullying di sekolah, di antaranya: faktor penampilan korban, lingkungan, pengalaman masa lalu, perasaan iri, dan latar belakang keluarga. Perilaku bullying tidak bisa dibiarkan sebab menimbulkan dampak negatif pada siswa yang menjadi korban. Rigby (1999) mengemukakan bahwa anak yang menjadi korban bullying akan merasa terganggu secara psikologis, seperti gugup, cemas, kurang tidur, takut, tidak mau melakukan apapun, membenci sekolah dan merasa stres setiap pagi ketika harus ke sekolah. Adapun secara fisik akan terlihat anak mengeluh sakit di bagian tertentu seperti di kepala, lutut, kaki, atau bahu. Bahkan bisa sampai demam dan muntah.

Hal yang sama terjadi di SMA Negeri 1 Barumun. Berdasarkan hasil pengamatan peneliti di SMA Negeri 1 Barumun, bahwa terdapat beberapa siswa yang sering menjadi korban bullying di sekolah. Beberapa di antaranya merasa tertekan secara psikologis, seperti gugup, cemas, tiba-tiba menjadi pendiam, murung, penakut, stres dan tidak mau bergaul. Bentuk bullying yang diterima secara verbal ataupun non verbal. Namun, para korban bullying sering tidak berani untuk melawan ataupun mengadu kepada guru, sehingga gangguan psikologis yang dihadapi semakin hari semakin berat. Yang paling mengkhawatirkan adalah, besar kemungkinan para korban bullying suatu saat akan menjadi pelaku bullying. Berdasarkan paparan di atas, maka peneliti tertarik untuk meneliti Dampak Psikologis Korban Bullying (Studi Kasus di SMA Negeri 1 Barumun)

\section{METODE}

Penelitian ini penulis rancang dengan menggunakan rancangan deskriptif kualitatif dengan pendekatan fenomenologis. Deskriptif yaitu suatu penelitian yang dirancang untuk memperoleh informasi tentang status gejala pada saat penelitian dilakukan. Kualitatif yaitu sesuatu yang digambarkan dengan kata-kata atau kalimat berpisah-pisah menurut kategori untuk memperoleh kesimpulan diskriptif kualitatif adalah suatu penelitian yang dirancang untuk memperoleh informasi dalam rangka mencari kesimpulan yang digambarkan dengan kata-kata.

Metode pengambilan data dalam penelitian kualitatif sangat beragam dan harus disesuaikan dengan masalah yang akan diteliti, tujuan penelitian, serta sifat objek yang diteliti. Pada penelitian ini peneliti hanya menggunakan metode observasi, wawancara, dan dokumentasi.

Sesuai dengan tujuan penelitian ini, karakteristik responden yang dipilih adalah kriteria : a) siswa kelas X dan XI SMA Negeri 1 Barumun, dan b) korban bullying. Dalam penelitian ini, terdapat tiga orang responden, yaitu: 
Tabel 4.1

Responden penelitian

\begin{tabular}{|c|c|c|c|c|}
\hline No & Nama/inisial & $\begin{array}{c}\text { Jenis } \\
\text { kelamin }\end{array}$ & Kelas & Usia \\
\hline 1 & SM & $\mathrm{P}$ & $\mathrm{X}$ & $\begin{array}{c}16 \\
\text { tahun }\end{array}$ \\
\hline 2 & NS & L & XI & $\begin{array}{c}17 \\
\text { tahun }\end{array}$ \\
\hline
\end{tabular}

Analisis tematik bukan merupakan metode kualitatif baru yang dikembangkan, melainkan suatu proses yang digunakan dalam mengolah informasi kualitatif. Analisis tematik adalah proses yang dapat digunakan dalam hampir semua metode kualitatif, dan memungkinkan penerjemahan gejala atau informasi kualitatif menjadi data kualitatif seperti kebutuhan peneliti (Boyatzis, dalam Poerwandari, 2017).

Analisis tematik merupakan proses mengkode informasi yang dapat menghasilkan daftar tema, model tema atau indikator yang kompleks, kualifikasi yang biasanya terkait dengan tema itu, atau hal-hal diantara gabungan yang telah disebutkan.

Istilah yang pertama dan paling sering digunakan peneliti kualitatif adalah kredibilitas. Kredibilitas menjadi istilah yang paling banyak dipilih untuk mengganti konsep validitas, dimaksudkan untuk merangkum bahasan tentang kualitas penelitian. Kredibilitas kualitatif terletak pada keberhasilannya mencapai maksud mengeksplorasi masalah atau mendeskripsikan setting, proses dan kelompok sosial atau pola interaksi yang kompleks. Konsep kredibilitas juga harus mampu mendemonstrasikan bahwa untuk memotret kompleksitas hubungan antara aspek tersebut. Penelitian dilakukan dengan cara tertentu dan menjamin bahwa subyek penelitian diidentifikasikan dan dideskripsikan secara akurat (Poerwandari, 2017).

Hal-hal penting untuk meningkatkan validitas dan generalitas pada penelitian kualitatif adalah dengan melakukan metode triangulasi. Triangulasi mengacu pada upaya mengambil data dari sumber-sumber yang berbeda, dengan cara yang berbeda, untuk memperoleh suatu kejelasan mengenai suatu hal tertentu. Triangulasi dapat dibedakan menjadi beberapa bentuk yaitu: 1) triangulasi data; yaitu menggunakan sumber data yang berbeda, 2) triangulasi peneliti; yaitu menyertakan beberapa peneliti dan evaluator yang berbeda, 3) triangulasi teori; yaitu menggunakan perspektif yang berbeda untuk menginterpretasikan data yang sama, 4) triangulasi metode; yaitu menggunakan metode yang berbeda untuk meneliti suatu hal yang sama. (Moleong, 2012).

Penelitian ini akan menggunakan triangulasi data, triangulasi peneliti, triangulasi teori dan triangulasi metode. Triangulasi data dilakukan dengan menggunakan sumber data yang berbeda yaitu beberapa informan. Triangulasi peneliti dilakukan dengan cara menggunakan evaluator yang berbeda untuk mengevaluasi hasil penelitian. Triangulasi teori dilakukan dengan menggunakan teori yang berbeda untuk menginterpretasikan hal yang sama. Adapun teori pokok yang akan digunakan adalah teori mengenai bullying. Triangulasi metode dilakukan menggunakan metode yang berbeda untuk meneliti hal yang sama. Adapun metode yang digunakan adalah metode wawancara, observasi dan dokumentasi. Penggunaan keempat triangulasi tersebut diharapkan menyebabkan hasil penelitian ini dapat dipertanggungjawabkan.

Dependability merupakan konsep yang dapat menggantikan konsep realibilitas yang diusulkan oleh Lincoln \& Gubn dalam Poerwandari (2017). Melalui konsep ini, peneliti memperhitungkan perbedaanperbedaan yang mungkin terjadi menyangkut fenomena yang diteliti, juga perubahan dalam desain sebagai hasil dari pemahaman yang lebih mendalam tentang setting yang diteliti.

\section{HASIL DAN PEMBAHASAN}

Pelaksanaan penelitian dengan subjek dilakukan di sekolah. Subjek penelitian merupakan 2 siswa kelas $\mathrm{X}$ dan XI SMA Negeri 1 Barumun Kabupaten Padang Lawas. Peneliti menyamarkan nama subjek, kedua subjek bernama SM dan NS. Kedua subjek memiliki kehidupan bersosial yang berbeda.

Penelitian dengan subjek dimulai pada tanggal 15 Agustus 2018 dimulai dengan perkenalan menentukan perjanjian untuk wawancara tanpa ada unsur paksaan, SM 
menyanggupi dan dilanjutkan melakukan wawancara pertama dengan subjek SM. Pada tanggal 19 Agustus 2018 peneliti melakukan observasi Alena saat di perpustakaan, Alena sedikit ngobrol dengan peneliti sambi melirik pelaku bullying seperti orang ketakutan.

Pada tanggal 21 Agustus 2018 peneliti melakukan observasi kedua saat kegiatan belajar mengajar berlangsung mata pelajaran bimbingan dan konseling selama kurang lebih 40 menit. Waktu istirahat kedua peneliti melakukan wawancara kedua dengan subjek berlangsung selama kurang lebih 30 menit.

Penelitian dengan subjek NS dilakukan tanggal 19 Agustus 2018. Peneliti melakukan observasi saat istirahat di teras depan kelas dan di kantin, kemudian peneliti melakukan wawancara pertama dengan Gino saat istirahat kedua di ruang Bimbingan dan Konseling. Observasi kedua peneliti lakukan di kelas pada tanggal 23 Agustus 2018 saat kegiatan belajar mengajar mata pelajaran Bimbingan dan Konseling di kelas tempat NS belajar, kemudian peneliti melakukan wawancara kedua dengan NS di sela-sela jam kosong di kelasnya.

Peneliti mewawancarai secara mendalam hal yang telah diberikan oleh Subjek, teman Subjek, wali kelas Subjek dan Guru BK Subjek di lingkungan Subjek sekolah. Wawancara dilakukan secara terstruktur dan tidak terstruktur. Peneliti sudah menyiapkan pedoman pertanyaan penelitian yang akan ditanyakan kepada subjek dan peneliti juga melakukan wawancara secara tidak terstruktur dengan memberikan pertanyaan lebih mendalam kepada subjek. Adapun hasilnya wawancara sebagai berikut :

\section{Bentuk Bullying Yang Dialami Oleh Korban Di Sekolah}

Bentuk bullying yang dialami SM merupakan jenis bullying verbal dan bullying psikologis. Pernyataan tersebut dapat dilihat pada hasil wawancara dengan alena bahwa ia mengatakan :

“Ya saya menjauhi teman yang suka mengejek saya lagian teman yang sering teriakteriak ngejek saya juga jauhin saya"

"ya yang neriakin genderuwo, genderuwo gitu mbak, sebel banget kan"

Diperkuat dengan hasil observasi saat peneliti mengikuti kegiatan belajar mengajar di kelas SM saat mata pelajaran. SM terlihat tidak mempunyai teman, dan satu teman disampingnya terlihat memandang SM seperti orang yang menjijikkan dan tidak menarik untuk dilihat.

Hal yang sama dialami oleh NS, sering kali dijadikan korban bullying dengan temanteman nya di kelas, NS merupakan korban jenis bullying fisik dan verbal. Pernyataan ini dapat dilihat pada hasil wawancara, bahwa :

"Ya aku kan gak terlalu pinter, trus kalau dalam kelompok aku disuruh maju depan kelas, menjawab pertanyaan salah gitu, trus dibentakbentak sama temen di kelompok, kadang juga pas mau jawab pertanyaan salah dibentakbentak teman satu kelas mbak"

"Ya pas salah jawab soal di depan kelas gitu, trus dibilang bodoh, goblok gitu-gitu mbak"

"Saat itu kan pernah aku masih kelas 7, teman kelas sebelah sengaja menginjak kaki saya, melempar-lempar topi saya, saya bales trus hampir berantem"

Hasil wawancara yang sama dikatakan oleh wali kelas NS bahwa:

"Lalu ada laporan dia berantem dengan teman kelas lain, berantem nya juga pukul-pukulan gitu mbak, itu Cuma gara-gara kaki gino diinjak dan topi nya gino di lempar lempar begitu".

Diperkuat dengan hasil observasi yang peneliti lihat saat mengikuti kegiatan belajar mengajar di kelas NS. NS mengalami perilaku bullying verbal, ia dikatakan "goblok" dengan teman satu kelas nya saat NS menjawab pertanyaan dengan suara sangat pelan. Dari pernyataan di atas dapat diambil kesimpulan bahwa SM dan NS adalah korban perilaku bullying Verbal, Non verbal dan psikologis.

\section{Faktor yang menyebabkan korban di bully}

Perilaku bullying yang dialami oleh korban karena adanya faktor sifat dalam diri korban yang pendiam dan introvert serta mempunyai fisik yang tidak menarik di lingkungan usia para siswa remaja. Pernyataan tersebut dapat dilihat dari hasil wawancara wali kelas dan teman dekat SM :

"sebenernya awal dari dia di bully itu karena dia tidak mau berbaur dengan temannya di kelas, jadi teman-teman nya merasa gemes dengan dia, lalu di bully sering di jodohjodohkan"

"ya kata teman-teman sih alena itu jelek mbak" 
Begitu juga dengan perilaku bullying yang dialami oleh NS sebagai subjek kedua, perilaku bullying yang dialami NS karena adanya faktor keterbatasan kognitif dan fisik.

\section{Dampak Bullying}

Berdasarkan hasil wawancara dengan SM dan NS terkait dengan perilaku bullying yang dialami di lingkungan kelas maupun di sekolah dapat menghambat perkembangan sosial SM dan NS, subjek merasa tidak nyaman lalu merasa minder dan merasa tidak dihargai sehingga subjek membatasi diri dalam bersosial. Pernyataan tersebut dapat dilihat pada hasil wawancara, bahwa:

"Ttrauma sih mbak, makanya gak mau dekatdekat dia dan gak mau bales perlakuan dia mbak"

Hal yang sama dikatakan oleh wali kelas NS bahwa :

"Dia seperti ada rasa trauma mbak karna dia pernah berantem itu, dia mempunyai rasa takut yang lebih tinggi dan ditambah dengan dia yang pendiam”.

Dilihat dari hasil pernyataan di atas dapat disimpulkan bahwa dari perilaku bullying yang diterima NS menghambat perkembangan sosial NS di sekolah. NS mengalami lebam di bagian tubuhnya dan trauma dengan salah satu teman di kelasnya karena pernah dipukul dan NS tidak berani membalas.

Sedikit berbeda dengan NS yang memiliki prinsip berbeda, SM memang tidak mempunyai teman di kelasnya dan SM pasif saat di kelas hingga dia merasa kecewa. Namun, SM sangat aktif dan memiliki banyak teman ketika dia berada di luar kelas atau di kelas lain.

Selain itu SM juga merasa tidak nyaman belajar di kelas nya.

Dilihat dari pernyataan di atas disimpulkan bahwa SM membatasi sosial di kelas nya, dan lebih merasa nyaman di lingkungan luar kelas nya.

Hasil observasi dari kedua subjek terlihat bahwa dampak perilaku bullying yang sangat terlihat yaitu kedua subjek menjadi pribadi yang penakut dan tidak percaya diri, sesuai dengan hasil observasi kedua subjek saat menjawab pertanyaan dari guru dengan suara sangat pelan. Subjek juga kurang fokus dalam mengikuti belajar di kelas, kedua terlihat melamun saat kegiatan belajar mengajar berlangsung.
Hasil dari wawancara dan observasi dapat diambil kesimpulan bahwa bentuk perilaku bullying yang dialami subjek merupakan bentuk fisik, verbal dan psikologis. Subjek NS mengalami bullying verbal dengan ejekan dan psikologis yaitu dijauhi teman di kelas dan digosipkan, berbeda dengan SM meskipun sama bullying verbal namun NS cenderung diejek mengenai kognitif dan prestasi akademiknya. Perilaku bullying fisik dialami oleh NS, dia mengalami bullying fisik didorong dan dipukul dibagian bahu, perilaku tersebut terjadi karena dia dianggap mempunyai fisik yang kecil dan lemah. Perilaku bullying psikologis yang dialami NS karena NS dianggap jelek dilingkungan teman-teman di kelasnya.

Beberapa perilaku bullying yang dialami kedua subjek diatas berdampak pada pribadi subjek yaitu subjek menjadi pendiam, terlihat sedih dan menangis sehingga memiliki rasa trauma dan menarik diri dari lingkungan di kelas nya. Dampak perilaku bullying yang dialami SM di kelas berdampak kepada SM bahwa ia saat ini sangat pasif saat di kelas, sehingga Alena merasa tidak nyaman di kelas dan ingin pindah kelas. NS merupakan korban bullying yang memiliki dampak sebagai pelaku bullying kepada pelaku yang membully NS karena, dia merasa marah dan tidak dapat menerima perlakuan dari temannya meskipun SM hanya berani membalas dengan orang tertentu.

\section{B. Pembahasan \\ 1. Bentuk Bullying}

Hasil dari wawancara kepada subjek terdapat 3 bentuk bullying yaitu verbal, non verbal atau fisik dan psikologis. Bullying verbal merupakan bentuk bullying dengan ucapan dari pelaku kepada korban, bullying fisik merupakan adanya sentuhan antara pelaku dan korban. Bullying psikologis merupakan bullying yang tidak terlihat dengan mata tanpa tatapan yang jeli karena bullying psikologis hanya dapat diketahui pelaku dan korban. Kedua subjek sebagai korban bullying sama sama mengalami bullying verbal tetapi subjek SM juga mengalami bentuk bullying psikologis.

NS sering diejek dan dijauhi oleh temanteman di kelasnya, SM sering kali diejek sebagai siswa yang berpenampilan jelek lalu dijauhi oleh teman-temennya di kelas 
(WSAPB-1). Berbeda dengan subjek kedua sebagai korban bullying, SM memang sama mengalami bentuk bullying verbal, tetapi SM juga mengalami bentuk bullying fisik. Hingga saat ini NS masih mengalami bullying verbal, diejek sebagai siswa yang memiliki kulit gelap dan SM mengalami bullying fisik, ia didorong dan dipukul dibagian tubuh nya.

Hal tersebut sesuai dengan pendapat Sejiwa yang telah di paparkan, ada beberapa jenis dan wujud bullying, tapi secara umum, praktik-praktik bullying dapat dikelompokkan ke tiga kategori : bullying fisik, bullying verbal, dan bullying mental/psikologis (Sejiwa, 2008). Bentuk bullying fisik yaitu : memukul, mencubit, mendorong, menarik, menampar. Bentuk bullying verbal yaitu : memaki, menghina, meneriaki, menuduh, menyoraki, menggosip, memfitnah. Sedangkan bentuk bullying psikologis yaitu : mendiamkan, mengucilkan, memelototi, mempermalukan.

Dari beberapa paparan di atas peneliti dapat menyimpulkan bahwa bentuk bullying yang dialami kedua subjek merupakan bentuk bullying verbal, fisik, dan psikologis. Tetapi setiap subjek mengalami bentuk bullying yang berbeda. NS sebagai mengalami bentuk bullying verbal ejekan dan bentuk bullying psikologis yaitu dijauhi teman-teman di kelas. NS mempunyai kesamaan dengan NS sebagai korban bullying verbal, tetapi NS juga mengalami bentuk bullying fisik yaitu didorong dan dipukul.

Kedua subjek mengalami ketiga bentuk bullying yaitu fisik, verbal, dan psikologis. Bullying fisik dialami oleh NS yaitu didorong saat baris dan dipukul bagian bahu. SM dan NS sama sama mengalami bullying verbal yaitu, pada SM ia diejek sebagai cewek yang jelek dan digosipkan. Bullying verbal yang dialami NS yaitu ia diejek sebagai siswa yang bodoh. Bullying psikologis dialami oleh NS yaitu dijauhi oleh teman di kelasnya. Hal ini sesuai dengan pendapat (Sejiwa, 2008) bahwa bentuk bullying terbagi menjadi tiga yaitu bullying fisik, bullying verbal, dan bullying psikologis.

Sama hal nya dengan bentuk bullying yang dikemukakan oleh Sullivan, meskipun bullying tebagi menjadi dua bentuk yakni perilaku bullying secara fisik dan non-fisik. Namun dalam bentuk bullying non- fisik merupakan bentuk bullying verbal dan non verbal, bentuk bullying verbal yakni meledek, mengancam, menghasut. Bentuk bullying non verbal yaitu menatap, menakuti, mengasingkan.

\section{Faktor Bullying}

Hasil dari wawancara dapat dikeatahui bahwa kedua subjek sebagai korban bullying mempunyai fisik yang hampir sama, berbadan kecil, kurus dan berkulit gelap sehingga menurut teman sebaya nya fisik yang tidak menarik di lingkungan usia remaja. SM sebagai korban bullying merupakan siswa yang berfisik kecil, lemah, memiliki pendapat yang berbeda dan tidak menarik menurut teman-teman nya.

SM diketahui penyebab dia dibully karena fisik dia yang kecil, diam, lemah, rendah percaya diri, keterbatasan kognitif, sulit bergaul, dan tidak menarik di lingkungan usia remaja, sehingga sering dijadikan bahan bully di kelas maupun di sekolah nya.

Pernyataan tersebut menjelaskan bahwa NS sebagai korban bullying disebabkan karena diri Gino sendiri secara fisik masuk dalam kategori mudah untuk dibully.

Dari paparan di atas dapat peneliti simpulkan bahwa faktor yang menyebabkan subjek sebagai korban bully ialah siswa yang mempunyai fisik kecil, lemah, kurang percaya diri dan susah menyesuaikan dengan lingkungan belajarnya. Teman-teman nya dengan mudah melakukan bullying dan dilakukan secara berulang-ulang karena tidak ada perlawanan dari korban. Perilaku bullying dapat dilakukan pelaku terhadap korban bullying hampir setiap hari saat di sekolah.

Pernyataan di atas sesuai dengan pendapat Sejiwa (2008) bahwa pelaku bullying biasanya dengan mudah bisa mengendus calon korbannya. Pada pertemu pertama, pelaku bullying akan melancarkan aksinya terhadap sang korban. Ciri-ciri korban yang dapat memicu adanya bullying adalah berfisik kecil, lemah, sulit bergaul, kurang percaya diri, memliki aksen yang berbeda, kurang pandai, tidak cantik atau tidak ganteng. Begitu juga dengan yang peneliti temukan di sekolah bahwa korban yang mudah untuk dibully yaitu siswa yang mempunyai fisik kecil dan pendiam atau sangat memilih-memilih teman di sekolah.

\section{Dampak Bullying}

Korban bullying mengakui bahwa dampak dari bullying yang dialami nya mengganggu belajar dan perkembangan subjek di sekolah, hingga melukai korban. NS 
mengakui dirinya sakit lebam, takut, nggak nyaman dan trauma. Sesuai dengan pernyataan wali kelas SM bahwa SM memiliki rasa trauma sehingga dia sangat menjaga jarak dan tidak mau lagi bergaul dengan teman kelas lain karena takut

Begitu juga SM mengakui bahwa ia merasa sedih, malu, marah di kelas, sehingga dia malas dan ingin pindah kelas.

Dari paparan tersebut dapat peneliti simpulkan bahwa perilaku bullying mempunyai dampak yang negatif sehingga dapat mengganggu korban dalam belajar, bersosial maupun berkembang. Korban bullying menjadi individu yang penakut, menarik diri, tidak bersemangat pergi sekolah, kurang percaya diri, kurang konsentrasi serta turun nya prestasi belajar korban.

Hal tersebut sesuai dengan pendapat Sejiwa (2008) bahwa Bila awalnya anak selalu meraih nilai tinggi dan tiba-tiba nilai nya merosot, sesuatu pasti telah terjadi. Apalagi jika ditambah dengan sulitnya konsentrasi, ekspresi lesu, depresi dan ketakutan, dampak lainnya adalah minta pindah sekolah, konsentrasi anak berkurang, menangis, tidak bersemangat, menajdi pendiam, menyendiri, tidak percaya diri dan mudah cemas bahkan ada keinginan untuk bunuh diri.

Namun, apabila korban bullying di sekolah dapat didampingi dengan baik, maka dampak bullying yang dialami akan menjadi dampak yang positif bagi korban. Korban akan menjadi pribadi yang baik dan dapat menerima dirinya sehingga rasa percaya diri lebih meningkat.

Pernyataan tersebut sesuai dengan pernyata Sejiwa (2008) bahwa Patut diingat bahwa bullying tidak bisa dihadapi dengan bullying. Jika anak kita dipukul anak lain, janganlah ajari ia memukul balik, karena yang terjadi nantinya hanyalah perkelahian. Kita bisa mengajak anak kita belajar ilmu bela diri karena paling tidak anak diajari kekerasan namun cara-cara menghindarkan kekerasan.

Peneliti menyimpulkan bahwa bentuk bullying yang dialami subjek SM mempunyai dampak disegala aspek dampak bullying yaitu pada aspek fisik SM menangis, pada aspek Psikologis SM minder, penakut, sedih, malu dan marah. Pada aspek Sosial SM menarik diri dan pada aspek Akademik SM ingin pindah kelas dan pasif.

Bentuk bullying yang dialami NS mempunyai dampak dalam segala aspek yaitu, dalam aspek fisik NS mengalami memar dibagian bahu dan merasa sakit. Dalam aspek psikologis NS minder, merasa takut, dan trauma sehingga mempengaruhi aspek sosial yang menarik diri dari teman yang pernah melakukan bullying kepada NS. NS juga tidak mengalami perkembangan dalam prestasi akademik di sekolah.

Dampak yang dialami NS juga sesekali ia menjadi pelaku bullying terhadap temannya meskipun ia hanya berani melakukan bullying kepada teman tertentu. Dampak fisik yang terjadi pada korban bullying yaitu korban merasa sakit pada bagian tubuh dan meninggalkan bekas memar, selain itu juga korban terlihat menangis dan sedih. Dampak sosial yang dialami korban bullying yaitu korban menarik diri dari teman-teman dan lingkungan belajar di kelas.

Dampak psikologis yang dialami kedua korban bullying yaitu minder, penakut, trauma, malu, marah dan tidak percaya diri. Dampak akademik yang dialami korban yaitu sangat pasif saat pelajaran berlangsung, tidak ada perkembangan dari hasil belajarmya, hingga ingin pindah kelas.

Dampak-dampak bullying yang telah dialami oleh subjek sangat mempengaruhi perkembangan siswa di sekolah apabila tidak didampingi dengan baik maka, perlu peranan dari guru BK di sekolah untuk dapat memberikan layanan dengan mendampingi siswa sebagai korban bullying dengan bimbingan secara pribadi maupun klasikal agar dapat merubah dampak negatif tersebut menjadi dampak yang positif sehingga siswa dapat tumbuh kembang dengan memulai penerimaan diri nya.

\section{SIMPULAN}

Berdasarkan hasil penelitian dan pembahasan hasil penelitian dapat disimpulkan beberapa hal berikut sebagai jawaban atas pokok permasalahan dalam penelitian ini :

1. Peneliti menyimpulkan bahwa bentuk bullying yang dialami subjek di sekolah adalah ketiga bentuk bullying yaitu bullying fisik, verbal, dan psikologis. 
Bullying yang dialami oleh subjek SM adalah ejekan dan bullying psikologis yaitu dijauhi oleh teman-temannya. Demikian dengan bullying yang dialami oleh subjek NS adalah bullying fisik yaitu dipukul, didorong dan bullying verbal yaitu dijuluki dan diejek siswa bodoh.

2. Faktor yang menyebabkan siswa dibullying yaitu cenderung dikarenakan adanya siswa yang mempunyai fisik kecil dan lemah, siswa yang kurang percaya diri, susah menyesuaikan dengan lingkungan, dan dianggap tidak menarik di lingkungan usia remaja seperti siswa yang mempunyai kulit sawo matang, rambut ikal, dan lain sebagainya.

3. Bullying di sekolah mempunyai dampak yang dapat menghambat perkembangan siswa di sekolah, korban bullying merasa takut lalu menarik diri dari teman-teman di kelas nya, menjadi pasif dan merasa kurang fokus mengikuti kegiatan belajar mengajar di kelas. Korban bullying fisik merasakan sakit dan meninggalkan luka lebam dibagian tubuhnya, sehingga ia takut dan trauma untuk bersosial dengan pelaku bullying tersebut.

\section{DAFTAR RUJUKAN}

Aznan. A. 2008. Faktor-faktor yang mempengaruhi Bullying pada Remaja. Jurnal Psikologi. Vol. 5. No. 1

Krahe B. (2005). Perilaku Agresif: Buku Panduan Psikologi Sosial. (Prajitno \& Mulyantini, Eds.). Yogyakarta: Pustaka Pelajar. Lee. (2009). School, Parents, and Peer Factor in Relation

Minauli, Irna. 2008. Metode Observasi. Medan: USU Press

Poerwandari. 2017 Poerwandari, E.K. 2017. Pendekatan Kualitatif untuk Penelitian Perilaku Manusia. Jakarta: Lembaga Pengembangan Sarana Pengukuran dan Pendidikan Psikologi Fakultas Psikologi Universitas Indonesia.
Riauskina, Djuwita, \& Soessetio. (2005). "Gencet-Gencetan" di Mata Siswa/Siswi Kelas 1 SMA: Naskah Kognitif tentang Arti, Skenario dan Dampak "GencetGencetan.

Rigby. K. 1999. What harms does bullying do? Journal of psychiatry

Saifullah, Fitrian. (2016). Hubungan Antara Konsep Diri dengan Bullying Pada Siswa Siswi SMP. eJorunal Psikologi.

Sejiwa. 2008 Bullying : Mengatasi kekerasan di sekolah dan lingkungan sekitar anak. Jakarta : PT Grasindo.

Wiyani. (2012). Save Our Children from School Bullying. Yogyakarta: Ar-Ruzz Media. 